\title{
How Employment Law Became a Major Issue for Hotel Operators
}

\section{by DAVID SHERWYN}

In the wake of new statutes and case law, issues relating to discrimination have expanded in the past twenty-five years to absorb a substantial amount of management time and attention. The basic law of discrimination is the Civil Rights Act of 1964, which created specific protect classes. That law was revised and expanded in 1991, and other causes of discrimination were added by such laws as the Americans with Disabilities Act and the Age Discrimination in Employment Act. Supreme Court decisions have clarified and expanded certain aspects of the laws, notably the definition of sexual harassment. Perhaps the fastest-growing complaint involves retaliation, in which employees seek to claim that unwanted employer actions result from some aspect of a civil rights complaint. While considerable confusion remains over certain aspects of discrimination law, employers should make every effort to properly instruct their supervisors and follow court-outlined procedures.

Keywords: Sexual harassment, ADA, Arbitration, Retaliation, Protected expression
7 he Cornell University School of Hotel Administration hired John E. H. Sherry, its first full-time law professor, in 1972. Reflecting the industry's key issues at that time, the school chose a real estate attorney. When it came time to name Professor Sherry's successor twenty-five years later, the school recognized the shifting sands of the industry's legal needs. Instead of a real estate lawyer, the school hired an employment lawyer as its only full-time law professor. The school's decision is emblematic of the rise of employment law as a concern for the hotel industry, particularly the area of discrimination claims. In this article, I examine key changes in discrimination law in the past twenty-five years, a period when the landscape of labor and employment law has changed drastically. In addition to discrimination-related issues, major changes in employment law include the following: Wage and hour cases, considered a nuisance in 1985, are now "bet the company lawsuits" (see Richmond and Sherwyn 2009). Unions, which seemed to be on the road to oblivion in 1985, seemed stronger in 2006 than they had been in thirty years. Since that high water mark, 
though, unions seem to be in a holding pattern as their internal strife continues and labor law reform languishes. Finally, terms that were unheard of in 1985 - blogs, email, facebook, and twitter-are now issues that industry employers are dealing with on a daily basis.

Even with all those developments, however, I argue that discrimination has become the most pervasive aspect of employment law. We have seen an unprecedented growth in the number of discrimination charges being filed, the codification of sexual harassment, a major change in how an employer's liability is assessed in harassment cases, the passing of the Civil Rights Act of 1991, the passing of the Americans with Disabilities Act of 1992 (ADA), a number of changes in the burden of proof, several new "protected classes," the astronomic increase in retaliation cases, and the remarkable rise of mandatory arbitration of discrimination cases. All of these have transformed the way hotel managers must address discrimination law. I address these issues in this article.

In 1989, approximately 120,000 discrimination charges were filed with the Equal Employment Opportunity Commission (EEOC) and various state and local agencies. In 2008 that number exceeded 190,000, an increase of almost 60 percent. The numbers, however, tell only a small part of the story, as explained below.

\section{Sexual Harassment}

Twenty-five years ago, sexual harassment was considered a violation of Title VII of the Civil Rights Act of 1964 by academics, employee advocates, and even the EEOC, but until 1986 neither Congress nor the Supreme Court had either defined or specifically outlawed it. That changed with the Supreme Court's decision in Meritor Savings Bank v. Vinson, when the Court held that harassment did violate Title VII. The Meritor Court held that there were two kinds of harassment. Quid pro quo harassment occurred, the court stated, when the employer demanded sexual favors in return for employment benefits or just for employment itself. ${ }^{1}$ The definition of a hostile environment was more complicated, ${ }^{2}$ and the court did not establish a clear definition in Meritor. The Court attempted to clarify this holding in 1994, with Harris v. Forklift Systems, in which the Court held that the conduct needed to be severe or pervasive from an objective and subjective standpoint. That holding still created confusion, but then the Court upped the ante with a subsequent holding.

For many years following Meritor, the majority of lower courts held that employers were always liable for quid pro quo harassment but were liable for hostile environment cases only when the employer knew or should have known of the conduct. In 1998, however, the Supreme Court did away with this distinction with two opinions, Burlington Industries v. Ellerth and Faragher v. Boca Raton. The Court held that employers would henceforth be liable for actions of supervisors who engage in either quid pro quo sexual harassment or hostile environment sexual harassment, regardless of whether the employer knew or should have known of the alleged

1. Quid pro quo is readily defined as wages, hours, or other terms and conditions of employment that are predicated on the acquiescence of unwanted sexual favors. Quid pro quo harassment occurs when, for example, an employer or its supervisors states, "Sleep with me or you are fired." In Ellerth, the Court clarified quid pro quo cases by holding that employees had to prove that they suffered a tangible loss to make the claim.

2. Hostile environment discrimination is defined as an employee being forced to endure unwelcome sexual conduct sufficiently severe or pervasive enough "to alter the conditions of [the victim's] employment and create an abusive working environment." 
conduct. The Court did establish, however, an affirmative defense that could be used in certain circumstances.

The affirmative defense rests on the following two issues: whether the employee suffered a "tangible loss" and whether the company can satisfy the Court's two prongs. The first prong is that employers must prove that they "exercised reasonable care to prevent and promptly correct any sexually harassing behavior," and the second is that they must show that the plaintiff "unreasonably failed to take advantage of any preventive or corrective opportunities provided by the employer or to otherwise avoid harm."

In neither holding, however, did the Court specify what might constitute reasonable care on the employer's part or when a complaining employee might be considered unreasonable. Since those decisions, judgments by lower courts have begun to illuminate at least some aspects of this picture, in particular, the nature of the employer's affirmative defense.

An analysis of seventy-two motions for summary judgment that employers filed after the Ellerth and Faragher decisions concluded, in regard to the first prong, that the courts determined that employers exercised reasonable care by having a "good sexual harassment policy," defined as one that is written, is disseminated, and provides an opportunity for employees to report to someone other than the harasser. With regard to the second prong, employee reporting, when employers exercised reasonable care and the employee did not report the harassment before filing suit, the court granted the employer's request for summary judgment every time. When the employee did report harassment to an employer who had exercised reasonable care, the courts generally found for the employer by holding that either (1) the employee was unreasonable because of delay, defect, or similar reason or (2) the employer's appropriate response absolved it of liability.

The matter is far from decided. Since that analysis in 2001, lawyers report that judges are not so quick to find all employees who do not make a report to be unreasonable and are less likely to find defects in employees who do report. Moreover, a number of states have rejected the affirmative defense outlined in Ellerth and hold employers strictly liable for supervisors' harassment. Although sexual harassment has gone from a concept to a codified area of law in the past twenty-five years, the standards for what constitutes sexual harassment and when the employer is liable continue to evolve, creating continued difficulty for employers.

\section{The Civil Rights Act of 1991}

The Civil Rights Act of 1991 introduced a new era for discrimination (Title VII) plaintiffs, because it allowed them to demand a jury trial, provided for punitive and compensatory damages for winning plaintiffs, and shifted the burden of proof in adverse impact cases to the employer. Additionally, the plaintiff can claim a mixed motive on the part of the employer, if the employee can prove with any kind of evidence that the employee's membership in a protected class was a part of the employer's motivation for an adverse

3. The Court explained this defense by asserting "proof that an employer had promulgated an anti-harassment policy with complaint procedure is not necessary in every instance as a matter of law." However, the Court did not explain how an employer could satisfy this burden without a policy. With regard to the employee's actions, the Court was again less than exact: "And while proof that an employee failed to fulfill the corresponding obligation of reasonable care to avoid harm is not limited to showing any unreasonable failure to use any complaint procedure provided by the employer, a demonstration of such failure will normally suffice to satisfy the employer's burden under the second element of the defense" (Ellerth, 118 S.Ct. at 10). 
employment decision. If the employee proves that the protected class motivated the employer, the employer is found guilty and will have to pay costs and attorney fees-even if the employer would have made the same personnel decision regardless of the fact of a protected class. Thus, an employer who terminates an employee for theft can still be liable for the fees if the jury finds evidence that the employer or its agent's prejudice motivated the decision in part.

It is difficult to overstate the effects of the Civil Rights Act of 1991. The costs of nuisance settlements rose exponentially because of employers' fear of jury trials and the increase in damages, which mushroomed from relatively modest back pay before the law to as much $\$ 300,000$ in punitive damages plus compensatory damages after passage (for employers of 500 people or more). In certain jurisdictions (e.g., Chicago, New York City) punitive damages are unlimited. With hundreds of thousands or even millions of dollars on the table, the days of settling cases for two weeks' pay and an apology are over. Combined with the relaxing of the standards necessary to receive a mixed motive analysis, the damage provisions have made discrimination lawsuits more expensive and more difficult to defend and settle.

\section{The ADA}

The most noteworthy new protected class in the past twenty-five years is persons with disabilities, expressly named in the ADA of 1992. With this law, the percentage of cases relating to protecting those with disabilities vaulted from 1.4 percent of discrimination cases filed in 1992 to 17.4 percent of discrimination lawsuits the following year.

Employers argue that the law misfired because the plaintiffs filing those numerous claims are not those whom the law sought to protect. This argument arises because the top two sources of claims are for bad backs and psychological disorders, rather than those with "classic" disabilities, such as hearing or vision impairments, missing limbs, or mental retardation. Altogether, classic disabilities made up only 10.3 percent of the cases, as compared with 13.1 percent for those with bad backs and 16.4 percent claiming psychological issues. Employers argue that the emancipation of the disabled was supposed to focus on the people who fell into the "classic" category, rather than people with bad backs or those who were "stressed out."

On the other side of the ledger, advocates for the disabled argue that the ADA plaintiffs of all types are unfairly treated by the EEOC and the courts, in large part because ADA plaintiffs are less successful than those alleging other discrimination causes. I cannot unravel those contentions here, but I note that the data are unclear, at best. My assessment is that the ADA is different from other discrimination causes, because of provisions in the statute itself.

The first test for a discrimination claim is that plaintiffs must demonstrate membership in a protected class. This is relatively straightforward for most discrimination cases (either you are a woman or you are not; either you are older than forty or you are not), but such is not the case for many ADA claims. What constitutes a disability remains controversial, because it is established case by case. We now know that HIV is considered a disability, for instance, but the definition of disability for attention deficit disorder and alcoholism depends on the severity of the condition and its effect on life activities. Moreover, new ADA regulations have changed the standard related to persons whose disabilities are resolved by medication to protect those with corrected 
disabilities, further complicating the matter of proof.

The second plank to establish a discrimination case is that the plaintiff must prove that she or he can perform the job. However, certain disabilities legitimately disqualify people from being able to perform specific jobs, which means that some employees would have difficulty establishing their minimal qualifications for some positions and, therefore, their membership in the protected class.

Finally, there is the issue of reasonable accommodation. Unlike laws governing other protected classes, the ADA imposes the cost of providing jobs for the disabled on the employer, which must provide reasonable accommodation. Also unlike laws governing other protected classes, employers can avoid this burden by proving that either the requested accommodation is unreasonable (i.e., that the costs outweigh the benefit to society) or by claiming it is an undue hardship (i.e., the employer cannot afford the accommodation). Only religious discrimination has similar language. By contrast, an employer cannot prevail in any other Title VII claim by arguing it cannot afford to employ a protected applicant or employee. Thus, the ADA is an area where the outcome of cases is constantly in flux.

\section{Retaliation}

Retaliation is perhaps the fastest-growing cause of action relating to discrimination. From 1993 to 2007, the percentage of retaliation claims more than doubled, from 15.3 percent of the total cases brought to 32.38 percent. One reason the percentages are so high is that retaliation is often "tacked on" to other discrimination claims. No firm data support that assertion, but the fact is that once a discrimination claim is lodged, it costs nothing more to also allege retaliation.

In addition to these tack-on claims, employees can file allegations when they are not members of a protected class and when the only evidence of discrimination is timing. Thus, in addition to the tack-on cases, retaliation opens the door to standalone claims, which many management lawyers believe are based on frivolous discrimination complaints that grant a form of temporary job security. The scenario invoked by those attorneys is that the employee is worried about termination and is setting up a claim of retaliation if termination occurs.

On a more practical level, retaliation is a relatively easy issue for employees to identify, juries to understand, and lawyers to get interested in. While discrimination can be subtle, retaliation follows a complaint or another clear action. Juries can understand why employers may be sufficiently angry to retaliate after being accused of discrimination (whether falsely or correctly). Because it is easy for employees to identify and juries to understand, plaintiffs' lawyers, who are rational actors and must decide whether to invest their time and money in each case with which they are presented, are often more interested in retaliation cases than other types of discrimination cases. A case where the employee can identify unlawful actions based on easily understandable unlawful motivation is attractive to such a jury member. Finally, as seen below, retaliation cases are simply easier to prove than are traditional discrimination cases.

\section{The Law of Retaliation}

Under Title VII of the Civil Rights Act of 1964, retaliation claims can arise out of the statute's participation clause or its opposition clause. Retaliation under the participation clause occurs when the employee participates in a Title VII case (or the necessary precursors, such as EEOC investigations). Retaliation under 
the opposition clause law occurs when an employee "opposes" a perceived Title VII violation. To establish a case under either clause, employees must prove that (1) they engaged in a "protected expression," (2) they were discriminated against, and (3) there is a link between the protected expression and the adverse employment action. Each element of the claim is the subject of significant case law, commentary, and confusion. Two cases, Crawford v. Metropolitan Government of Nashville and Davidson County and Burlington Northern Santa Fe Railway Co. v. White, address elements of the prima facie case. Crawford addresses the parameters of the opposition clause, and in White, the Supreme Court defined the term "discrimination."

As with many cases, both White and Crawford provided some answers but left a number of issues open. Both cases involved protected expression, which, in general terms, occurs when an employee complains that the employer is violating a discrimination law. An employee invokes the participation clause for protected expression when he or she takes part (usually, as a party or witness) in a Title VII, Age Discrimination in Employment Act (ADEA), or ADA proceeding (typically, an agency investigation or litigation). The opposition clause regarding protected expression applies to situations where the employee's complaint did not come as part of a discrimination proceeding and is, instead, based on an internal complaint or other notification to management. Regardless of which applies, it is important to note that the discrimination at issue does not have to involve the complaining employee.

An important case in this matter is Payne v. McLemore's Wholesale and Retail Stores (654 F.2d 113 [5th Cir. 1981]), in which the court found in favor of an employee who, the employer argued, had mistakenly accused the employer of violating discrimination laws. The accusation was made in good faith, the court found, because the employee truly believed that that the alleged conduct occurred. The good faith reasonable belief is a defense for employees and a hurdle for employers to clear in opposition clause cases. It is not, however, an issue in participation clause cases.

The participation clause protects an employee who participates in any Title VII procedure regardless of the extent of such participation. In fact, the EEOC guidelines state that the protection under the participation clause applies to testifying, assisting, and preparing affidavits in conjunction with a proceeding or investigation under Title VII, ADEA, ADA, or EPA. In other words, an employee who files an EEOC charge or who assists another in filing or preparing such a charge is henceforth in a protected class. This is true even if the charge is not true, not reasonable, or not even good faith. As the court in Deravin v. Kerik (335 F.3d 203-205 [2nd Cir. 2003]) stated, the participation clause "is expansive and seemingly contains no limits." No case illustrates this point better than Merritt v. Dillard Paper Company (120 F.3d 1181 [11th Cir. 1997]), where the court held that a company could not discharge an employee for his admitted sexual harassment when the admission of that harassment occurred during a Title VII testimony. Because a protected expression under the participation clause need not satisfy the good faith reasonable belief standard, plaintiffs' lawyers often seek to fit their cases into this clause.

With that background, returning to Crawford, the plaintiff was questioned as part of an internal sexual harassment complaint brought by another employee. Specifically, a human resource officer of the employer asked her whether she had ever witnessed any "inappropriate behavior" on the part of one Dr. Hughes, the school 
district's employee relations director. In response, she related several harassing actions.

The employer did not discipline the alleged harasser, but not long after it concluded its investigation, the company terminated Crawford for embezzlement. Crawford argued that she was terminated in retaliation for cooperating with the company's internal investigation. The employer contended that the employee never engaged in a protected expression because (1) she did not assertively oppose the harassment - she merely answered questions by investigators - and (2) she did not participate in an EEOC investigation or in litigation. Both the district and circuit courts dismissed the case, holding that to invoke the opposition clause the employee must instigate or initiate the complaint. Moreover, the courts held, the participation clause did not apply because this was simply an internal investigation.

The Supreme Court took a different approach by defining the opposition clause, based on the statutory language. The statute states that "the opposition clause makes it unlawful . . . for an employer to discriminate against any employee because he has opposed any practice made ... . unlawful . . . by this subchapter." This language does not, however, define the term "oppose." The Court addressed this fact by citing Perrin v. United States (44 U.S. 37 [1979]), stating, "The term "oppose," being left undefined by the statue, carries with its ordinary meaning . . . to resist or antagonize . . . ; to contend against; to confront; resist; withstand." With a definition in hand, the Court could now apply the facts to the law.

The Court held that Crawford's answers to the employer constituted opposition because the plaintiff gave an "ostensibly disapproving account of sexually obnoxious behavior." According to the Court, "Crawford's description of the louche goings-on would certainly qualify in the minds of reasonable jurors as resistant or antagoni[stic] to Hughes."

At first blush, this holding does not seem too problematic, but one can argue that the Court's holding expanded the definition of the term "oppose" to include passive conduct. For example, the Court stated that a supervisor who refused to terminate an employee in violation of Title VII had opposed an unlawful practice. While that example is not the holding of the case, it is cause for concern.

Seeing the problem involved in what might be characterized as "silent opposition," Justice Alito commented that this case does not hold that employees are protected even where they do not openly express their opposition to an allegedly unlawful practice, because the Court has not addressed this issue. Additionally, it is also well-settled law that vague complaints will not constitute a protected expression. Instead, employees must be specific in their claim.

Finally, it is clear that an employer cannot be liable for retaliation if it did not know that the employee engaged in a protected expression. Thus, an employee who never communicates opposition would not be protected.

Trying to assess whether the "opposing" employee was really in opposition or was a coconspirator is an outgrowth of Crawford, because she evidently participated in the generally rank behavior in this office. This issue can be settled as follows: an employee who complains is clearly opposing. Conversely, an employee who simply responds to a question may or may not be in opposition to the conduct. The employer argued that the plaintiff was not opposing because she was taking part in the objectionable behavior. The Court held that this was a factual question for the jury. While a factual question for the jury often means huge attorneys' fees for employers, 
this holding is not that problematic. Employers can solve this issue by asking the employees how they felt about the conduct and why they did not complain. In addition, the employer needs to investigate the interaction fully and interview any individual with knowledge of the employee's conduct. An employer who determines that the employee was participating in the harassment rather than opposing it cannot be liable. The law requires intent to establish retaliation against employees. Thus, it is not unlawful to terminate someone for engaging in unacceptable behavior. This is the case even if the employee is not a coconspirator but has "opposed" in an unclear or unacceptable manner.

Subsequent cases support my contention that while Crawford defined the opposition clause and may have even expanded the definition, there is no real effect for employers. Courts have long protected employees who complained of disorderly conduct through a variety of avenues, and Crawford simply codified this type of holding. Moreover, the potential problems associated with Crawford can be mitigated with documentation and sound legal advice regarding questions and actions that occur during a sexual harassment investigation.

Because the Crawford Court did not address the parameters of the participation clause, it is still an open question as to whether the participation clause covers internal company complaints. Employers should check the law in their jurisdictions to see whether their circuit has weighed in on the issue. Absent circuit law to the contrary, federal courts will analyze internal complaints under the Crawford standard and not the participation clause.

\section{White Expanded the Meaning of the Term "Discrimination"}

The second element of any retaliation case is proving that the employee was discriminated against. This was the topic of Burlington Northern Santa Fe Railway Co. $v$. White, which sought to resolve a split among the circuits about the term "discrimination." Two circuits had held that the term "discrimination" meant that the employee suffered some "ultimate" employment decision, like a failure to hire or a termination of employment, while three circuits had held that the alleged retaliation must simply yield an adverse effect on the terms, conditions, or benefits of employment.

Sheila White was a "track laborer" with Gang 321 in the Maintenance of Way Department at the BNSF Tennessee Yard. The job was not a glamorous one; it entailed track replacement and removal, transportation of materials, cutting brush, and clearing litter and spilled cargo. White, however, had experience working a forklift, which led Burlington's road master, Marvin Brown, to assign her to forklift duty shortly after her arrival. This became White's primary responsibility, even though she continued to perform some track laborer tasks.

Three months into the job, White complained to Brown about the sexual harassment White experienced at the hands of her immediate supervisor, Bill Joiner. Joiner was suspended for ten days and ordered to attend a sexual harassment training session, but White was relieved of her forklift duties, on the grounds that the terms of the collective bargaining agreement dictated that a "more senior man" should have the "less arduous and cleaner job."

In the months that followed, White filed three retaliation charges with the EEOC, not only regarding the reassignment but also for being suspended, allegedly for insubordination. In that situation, the company later determined through its internal grievance procedures that White had not been insubordinate and awarded her back pay for thirty-seven days.

After exhausting administrative remedies with federal and state agencies, White 
eventually filed a Title VII action in federal court. A jury found in her favor and awarded White $\$ 43,500$ in damages. The case found its way to the Supreme Court, in part to resolve the circuit split on the issue of what constituted an adverse action. The Court had to decide two things: (1) Does the law only forbid those retaliatory actions that are related to employment or the workplace? and (2) How harmful must a retaliatory action be to subsequently fall within the provision's scope?

First, the Court concluded-in no uncertain terms - that Title VII's antiretaliation provision cannot be read to cover only retaliatory acts related to employment. Turning its attention to the level of harm needed to make an instance of retaliation actionable, the majority held that "a plaintiff must show that a reasonable employee would have found the challenged action materially adverse, which in the context means it well might have dissuaded a reasonable worker from making or supporting a charge of discrimination." In adopting this standard set forth by the Seventh and D.C. Circuits, the majority highlighted three aspects: materiality, reasonableness, and context. It spoke of material adversity since "petty slights, minor annoyances, and simple lack of good manners" will normally not deter an employee from relying on Title VII's remedial mechanisms. It spoke of a reasonable employee because the standard for judging harm must be objective to avoid a plaintiff's "unusual subjective feelings." Finally, the majority phrased the standard in general terms because "the significance of any given act of retaliation will often depend upon the particular circumstances." To illustrate, the majority noted that a supervisor's refusal to invite an employee to lunch is normally a trivial, nonactionable slight. To retaliate, however, by excluding the same employee from a weekly training lunch that "contributes significantly" to his or her professional advancement might well deter a reasonable employee from complaining about discrimination and would therefore be unlawful.

Applying the new standard to White's case, the majority concluded that there was sufficient evidence to support the jury's verdict on her retaliation claims. It rejected Burlington's contention that the reassignment could not constitute retaliation where the former and present job duties fall within the same job description. It likewise rejected Burlington's argument that the suspension could not constitute retaliation since White was ultimately reinstated with back pay. The majority determined in both instances that a reasonable employee-looking at the prospect of the loss of a paycheck near Christmas or relegation to less desirable tasks - might well choose to withhold a discrimination complaint. As is to be expected, retaliation cases spiked after this decision, but it is unclear whether employees are succeeding more than before. Indeed, employees seeking to convert inconsequential conduct into actionable retaliation have found the courts unreceptive (see Toland v. Potter, 2007 U.S. Dist. LEXIS 42153, D. Kan. 2007; Simmons, 2006 U.S. Dist. LEXIS 65527; and Michael 2007 U.S. App. LEXIS 18154, at 5, 8).

Technically, White and Crawford expanded the definition and scope of retaliation, making it easier for plaintiffs to file retaliation cases. I expect, though, that neither White nor Crawford will cause major problems for employers who are cognizant of the law, document their actions well, and obtain legal advice when dealing with any employee who has made a claim of discrimination. Employers who follow these basic procedures should be able to protect themselves from future litigation and can avoid the potential pitfalls inherent in any expansion in employee's ability to succeed on legal claims. 


\section{Arbitration}

Prior to 1991, lawyers, judges, and scholars generally accepted that mandatory arbitration agreements were unenforceable with regard to cases filed under federal employment antidiscrimination statutes. ${ }^{4}$ This position was based on Alexander $v$. Gardner-Denver Co. (415 U.S. 36 [1974]), in which the Supreme Court held that an employee could proceed with a Title VII race discrimination case even after he suffered an adverse decision in a laborarbitration award. It is important to note that the arbitration clause at issue was pursuant to a collective bargaining agreement.

In its 1991 decision, Gilmer v. Interstate/ Johnson Lane Corp. (500 U.S. 20 [1991]), the Supreme Court held that the GardnerDenver ruling applied only to arbitration agreements contained in a collective bargaining agreement. As a condition of employment, Robert Gilmer had signed an agreement that he would arbitrate all disputes that arose out of his employment. When he was subsequently terminated, he alleged that the company discriminated against him because of his age, sixty-two, in violation of the Age Discrimination in Employment Act (ADEA, $i d$. at 23-24). Gilmer contended that the arbitration agreement was unenforceable under Gardner-Denver, but the Court disagreed because in that case the arbitration in that earlier case occurred pursuant to a collective bargaining agreement, as opposed to an individual contract. This decision was the first of numerous Supreme Court and Circuit Court opinions and literally hundreds of law review articles. Based on almost twenty years of law, I can conclude that today mandatory arbitration is lawful if the agreement is fair, except in the transportation industry. This is the case even in a union environment. To be fair, most jurisdictions simply look to the policy. Employers should note Congress may outlaw such agreements.

Qualified employment lawyers can draft polices that will be upheld. Arbitration advocates will contend that arbitration is private, faster, and less expensive than litigation. Critics will argue that arbitration is unfair. Arbitration is, in fact, private. Whether it is faster, less expensive, and fair is an empirical question that is in the process of being answered. So far, the results are favorable to arbitration.

\section{Conclusion}

As explained here, the legal landscape of the hospitality industry has changed substantially over the past twenty-five years, particularly in regard to employment law. From sexual harassment to the ADA to retaliation to arbitration, employers face novel causes of actions and must constantly attend to human resources policies. Along the way, the $C Q$ has featured numerous articles on employment law for the benefit of industry employers, and it will continue to do so.

David Sherwyn, J.D., is an associate professor of law at the Cornell University School of Hotel Administration (dss18@cornell.edu)

Richmond, C. D., David Sherwyn, and Martha Lomanno, with Vimisha Dubal and Jason E. Shapiro. 2009. Restaurants at the crossroads: A state by state summary of key wage-and-hour provisions affecting the restaurant industry. In Cornell Hospitality Roundtable Retrospective. Retrieved from http://www.ddifo.org/pdfs/CHR\%20Cornell\%20 Restaurants\%20at\%20a\%20Cross\%20Road.pdf.

4. See Alexander v. Gardner-Denver Co., 415 U.S. 36, 47 (1974) ("There is no suggestion in [Title VII] that a prior arbitral decision either forecloses an individual's right to sue or divests federal courts of jurisdiction."); see, e.g., Utley v. Goldman Sachs \& Co., 883 F.2d 184, 187 (1st Cir. 1989) (holding that Title VII claims are nonarbitrable in nonunion employment setting); Swenson v. Management Recruiters Int'l, Inc., 872 F.2d 264 (8th Cir. 1989) (distinguishing commercial from civil rights disputes in terms of mandatory arbitration). 